\title{
PERANAN PEMERINTAH DAN ATURAN AL-QUR'AN
}

\author{
Haqiqi Rafsanjani \\ Dosen Perbankan Syariah, Fakultas Agama Islam \\ Universitas Muhammadiyah Surabaya
}

\begin{abstract}
Abstrak
Dalam era perdagangan global sekarang ini, peranan pemerintah sangat diperlukan tetapi peranannya bukan lagi seperti di masa Orde Baru yang banyak memberikan monopoli dan proteksi kepada pelaku usaha tertentu serta badan usaha milik negara yang di kelola tidak efisien. Pada masa Orde Baru, pemerintah banyak mengeluarkan kebijakan ekonomi yang tidak konsisten, yang justru memberikan kemudahan kepada pelaku usaha tertentu. Akibatnya, mekanisme pasar menjadi terhambat. Ada tiga sistem ekonomi yang di kenal di dunia, yaitu Sistem ekonomi Sosialis, Sistem ekonomi Kapitalis, dan Sistem ekonomi Islam. Sistem ini mempunyai karakteristik masing-masing.
\end{abstract}

Kata kunci: Peran Pemerintah, Sistem Ekonomi 


\section{Latar Belakang}

Dalam rangka liberalisasi perdagangan dan pengembangan ekonomi domestik dibutuhkan pemerintah yang kuat untuk pengembangan ekonomi domestik sekaligus untuk menghadapi perdagangan global. Kesimpulan tersebut bertitik tolak dari kondisi perekonomian Indonesia yang belum mampu keluar dari krisis multidimensi dan sikap pemerintah dalam mengeluarkan kebijakankebijakan ekonomi. Di tambah lagi ketergantungan pemerintah kepada IMF dalam melaksanakan program-program (kebijakan-kebijakan ekonomi) khususnya pada industri strategis.

Dalam era perdagangan global sekarang ini, peranan pemerintah sangat diperlukan tetapi peranannya bukan lagi seperti di masa Orde Baru yang banyak memberikan monopoli dan proteksi kepada pelaku usaha tertentu serta badan usaha milik negara yang di kelola tidak efisien. Pada masa Orde Baru, pemerintah banyak mengeluarkan kebijakan ekonomi yang tidak konsisten, yang justru memberikan kemudahan kepada pelaku usaha tertentu. Akibatnya, mekanisme pasar menjadi terhambat.

Untuk mengkaji dan mengulas tentang peranan pemerintah dalam mengeluarkan kebijakan-kebijakan ekonomi, maka diperlukan sub pokok bahasan yang saling berhubungan, sehingga penulis membuat rumusan masalah sebagai berikut:

1. Bagaimana peranan pemerintah sebagai regulator dalam ekonomi?

2. Peranan pemerintah dalam mengatur distribusi barang dan harga?

\section{Peran Negara Dalam Ekonomi}

Peran negara dalam ekonomi ditentukan dari sistem perekonomian dan sistem pengelolaan ekonomi yang mereka gunakan. Sistem perekonomian ini akan sangat ditentukan oleh ideologi yang di anut oleh negara yang bersangkutan. Hal ini akan membedakan peran setiap negara dalam kegiatan perekonomian yang akan tergambar pada kebijakan yang dikeluarkan dalam mengelola perekonomian. Sehingga untuk mengetahui peran apa yang dimiliki oleh suatu negara maka kita perlu melihat ideologi dan sistem perekonomian negara tersebut.

Ada tiga sistem ekonomi yang di kenal di dunia, yaitu Sistem ekonomi Sosialis, Sistem ekonomi Kapitalis, dan Sistem ekonomi Islam. Sistem ini mempunyai karakteristik masing-masing.

\section{Sistem Ekonomi Sosialis}

Paham ini muncul sebagai akibat dari paham kapitalis yang mengekploitasi manusia, sehingga negara ikut campur cukup dalam dengan perannya yang sangat dominan. Akibatnya adalah tidak adanya 
kebebasan dalam melakukan aktivitas ekonomi bagi individu-individu, melainkan semuanya untuk kepentingan bersama, sehingga tidak diakuinya kepemilikan/ kekayaan pribadi. Paham sosialis ini merupakan paham yang bergerak menuju paham komunis.

Peran Negara dalam sistem ekonomi sosialis:

- Negara mengatur semua alat-alat produksi dan kebijaksanaan ekonomi.

- Pemerintah juga bertindak aktif mulai dari perencanaan, pelaksanaan, hingga tahap pengawasan.

- Negara bertanggung jawab dalam mendistribusikan sumber dan hasil produksi kepada seluruh masyarakat.

- Negara mengatur berbagai hal dalam ekonomi untuk menjamin kesejahteraan seluruh masyarakat.

- Negara juga memiliki peran untuk mengendalikan harga-harga dan penyaluran barang.

\section{Sistem ekonomi Kapitalis}

Berbeda dengan sistem sosialis, sistem ini sangat bertolak belakang dengan sistem Sosialis, di mana negara tidak mempunyai peranan utama atau terbatas dalam perekonomian. Sistem ini sangat menganut sistem mekanisme pasar. Sistem ini mengakui adanya tangan yang tidak kelihatan yang ikut campur dalam mekanisme pasar apabila terjadi penyimpangan (invisible hand). Yang menjadi cita-cita utamanya adalah adanya pertumbuhan ekonomi, sehingga setiap individu dapat melakukan kegiatan ekonomi dengan diakuinya kepemilikan pribadi. Peran negara di sini hanya berkaitan dengan hal-hal tertentu yang meliputi pertahanan keamanan, penegakan keadilan dan menyediakan dan memelihara sarana serta lembaga-lembaga publik tertentu. Peran negara tersebut dalam istilah Adam Smith dikatakan sebagai no intervetion atau Peran Minimal Negara.

Pada sistem ekonomi kapitalis ini negara memiliki 3 peranan yang merupakan peran fundamental yang menurut Adam Smith dengan peranan terbatas tersebut optimalisasi kesejahteraan individu pada lingkungan mikro dan negara pada lingkungan makro akan dapat tercapai. 3 peran tersebut, yaitu :

1. Peran yang pertama adalah negara mempunyai fungsi untuk menegakkan keadilan. Fungsi ini ditujukan untuk menjaga kebebasan tiap individu dalam sistem pasar bebas yang merupakan sistem sosial masyarakat modern.Pemerintah hanya akan melakukan intervensi jika terjadi ketidak adilan dan ketimpangan dalam interaksi pasar bebas. Untuk optimalisassi 
peran pemerintah dalam menjalankan keadilan, maka pemerintah harus bertindak adil. Dengan kata lain pemerintah tidak memihak kelompok manapun yang ada dalam masyarakat.Dalam hal ini ada tiga hal yang harus dilakukan pemerintah untuk mewujudkan keadilan dalam masyarakat :

- Harus ada pemisahan dan kemerdekaan antara kekuasaan ekskutif, legislatif dan yudikatif.

- Adanya pembatasan kekuasaan pemerintahan. Pembatasan di sini adalah bahwa pemerintah harus tunduk dan patuh pada hukum dan keadilan.

- Terdapat jaminan akan berlangsungnya kekuasaan oposisi. Artinya dalam rangka untuk mengkontrol kebijakan pemerintah, dibutuhkan sebuah kekuasaan di luar pemerintahan untuk menjamin dan mengawasi bahwa pemerintah akan senantiasa bertindak adil.

2. Peran yang kedua adalah pertahanan keamanan. Fungsi ini dimaksudkan negara wajib melindungi seluruh warga negaranya dari serangan dan ancaman dari bangsa dan negara lain. Dengan kata lain pemerintah tidak mencampuri langsung urusan ekonomi tetapi dengan cara melindungi seluruh warga negaranya sehingga tidak ada ancaman dalam melakukan kegiatan ekonomi.

3. Peran yang ketiga adalah menyediakan sarana dan prasarana publik. Dalam hal ini pembangunan sarana infrastuktur baik berkenaan dengan sistem pasar bebas maupun berkenaan dengan sarana publik seperti jalan dan yang lainnya adalah menjadi kewajiban pemerintah.

\section{Sistem Ekonomi Islam}

Sistem ekonomi Islam sudah ada jauh lebih dahulu dari kedua sistem yang dimaksud di atas, yaitu pada abad ke 6 , sedangkan kapitalis abad 17, dan sosialis abad 18. Dalam sistem ekonomi Islam, yang ditekankan adalah terciptanya pemerataan distribusi pendapatan. Selain itu negara berperan sebagai Pengawas (hisbah), yang mengawasi berjalannya sistem pasar sehingga terwujud mekanisme pasar bebas. Dalam Islam kepemilikian pribadi juga diakui, namun terhadap setiap umat Islam yang mempunyai penghasilan yang mencukupi (memenuhi hisab), sebagian dari hartanya adalah milik orang-yang tidak mampu (zakat). Dalam Islam pilar yang menjadi etika ekonomi yang tidak terdapat dalam sistem ekonomi lainnya adalah tauhid, keadilan, keseimbangan, dan kebebasan. 
Dalam memecahkan permasalahan perekonomian, berdasarkan fakta hakikat permasalahan ekonomi terletak pada bagaimana distribusi harta dan jasa di tengah-tengah masyarakat, sehingga titik berat pemecahan permasalahan ekonomi adalah bagaimana menciptakan suatu mekanisme distribusi ekonomi yang adil. Dalam sistem ekonomi islam Negara memberikan kebebasan dalam beraktivitas dalam perekonomian selain itu Negara mempunyai tanggung jawab untuk mengatur ekonomi dengan tujuan meningkatkan kesejahteraan rakyat sehingga pada akhirnya negara menjadi kuat.

Menurut Monzer Khaff, yang menjadi keterbatasan negara saat ini dalam menerapkan sistem negara islam adalah kurangnya komitment terhadap syariah, dan kurangnya komitmen terhadap shura (proses musyawaran untuk mufakat). Tetapi menurut Ibnu Khaldun, keruntuhan dan kejayaan suatu dinasti tidak hanya tergantung pada variabevariabel ekonomi namun tergantung dengan sejumlah faktor yang menentukan kualitas perorangan, masyarakat, pemerintahan dan Negara.

Hal-hal yang harus dilakukan dalam hal yang berkaitan dengan peran negara dalam perekonomian islam adalah:

- Memajukan sektor swasta dengan tetap memperhatikan kepentingan umum

- Sumber daya alam dikelola secara bersama, di mana pengelola menyewa lahan kepada umum

- Kebijakan investasi secara langsung

- Proyek yang dikerjakan oleh individu, tetap dapat dinikmati oleh orang banyak

- Memberantas kemiskinan dan menciptakan kondisi lapangan kerja dan tingkat pertumbuhan yang tinggi

- Meningkatkan stabilitas nilai riil uang

- Menegakkan keadilan sosial dan ekonomi

\section{Peranan Pemerintah Sebagai Regulator Dalam Ekonomi}

Friedman menjelaskan fungsi negara sebagai "regulator" (pengatur) mencakup berbagai cara di mana negara melakukan intervensi melalui penggunaan hukum publik dengan langkah-langkah dan instrumentalitas dari suatu masyarakat yang tidak teratur.

Berkaitan dengan berbagai macam instrumen hukum di mana negara modern melakukan kontrol atas aktivitas ekonomi masyarakat, hampir tidak terbatas. Friedman menjelaskan fungsi-fungsi kontrol digunakan baik oleh negara-negara dengan ekonomi sosialis dan negaranegara (seperti AS) yang umumnya bertentangan dengan perusahaanperusahaan pemerintah tetapi menggunakan kontrol legislatif, administratif 
dan judisial untuk mengurangi ketidaksamaan dan bahaya di mana suatu ekonomi yang tidak di atur terjadi dalam masyarakat dewasa ini. Selanjutnya dikatakan bahwa bentuk kontrol hukum yang paling representatif dapat diklasifikasikan dalam tiga kategori yakni:

1. Pembatasan hukum tentang kebebasan berkontrak dan properti

2. Kontrol hukum dimaksudkan untuk mengurangi kosentrasi kekuatan ekonomi yang berlebihan

3. Kontrol hukum dimaksudkan untuk memberikan perlindungan ekonomi nasional, khususnya di negara-negara sedang berkembang melalui regulasi keluar mesuknya uang dan barang di antara ekonomi nasional dan luar negeri.

Secara umum, ruang lingkup peranan pemerintah ini mencakup aspek yang luas, di mana secara garis besar diklasifikasikan menjadi:

a. Upaya mewujudkan tujuan ekonomi islam secara keseluruhan

b. Upaya mewujudkan konsep dasar yang islami

Pemerintah memiliki tugas penting dalam mewujudkan tujuan ekonomi islam secara keseluruhan. Sebagaimana telah diketahui, tujuan ekonomi islam adalah mencapai falah yang direalisasikan melalui optimasi maslahah. Oleh karena itu, sebagai pengemban amanah dari Allah SWT. Dan masyarakat, maka secara umum tujuan peran pemerintah adalah menciptakan ke-maslahah-an bagi seluruh masyarakat. Menurut AlMawardi tugas dari pemerintah adalah untuk melanjutkan fungsi-fungsi kenabian dalam menjaga agama islam dan mengatur urusan duniawi. Sementara, menurut Ibn Khaldun eksistensi pemerintah adalah untuk memastikan agar setiap orang dapat memenuhi tujuan syariat baik dalam urusan dunia maupun akhirat.

Teks Al-Qur'an dan Sunnah secara eksplisit dan implisit telah menyebutkan beberapa peran yang harus dilakukan pemerintah, baik yang dilakukan melalui pasar maupun bukan pasar. Peran-peran tersebut, yaitu sebagai berikut:

a. Manajemen kekayaan publik dalam rangka memaksimumkan kepentingan publik

b. Pemenuhan segala persyaratan untuk membangun negara yang secara efektif dapat melindungi masyarakat dan kepentingan budaya, ekonomi, religius, dan politik

c. Menggali pemasukan untuk membiayai administrasi publik dan tugas-tugas pemerintah

d. Menjamin para individu agar dapat meningkatkan efisiensi dan derajat kekayaan dan kesejahteraanya 
e. Menjaga keseimbangan sosial dan ekonomi, khususnya dalam distribusi dan redistribusi kekayaan/pendapatan

f. Melindungi lingkungan ekonomi agar tetap sesuai dengan nilai dan prinsip islam

Pemerintah memiliki peran penting dalam mewujudkan pasar yang islami. Intervensi pemerintah dalam pasar bukan hanya bersifat temporer dan minor, tetapi ia akan mengambil peranan yang besar dan penting. Pemerintah bukan hanya bertindak sebagai 'wasit' atas permainan pasar, tetapi ia akan berperan aktif bersama pelaku-pelaku pasar yang lain (coexisting). Pemerintah dapat bertindak sebagai perencana, pengawas, pengatur, produsen sekaligus konsumen bagi aktivitas pasar. Peran pemerintah dalam pasar ini secara garis besar dapat diklasifikasikan menjadi dua bagian, yaitu: pertama: peran yang berkaitan dengan implementasi nilai dan moral islam, kedua: peran yang berkaitan dengan teknis operasional mekanisme pasar.

\section{Peranan Pemerintah Dalam Mengatur Distribusi Barang Dan Harga}

Tidak ada satu negarapun di dunia ini yang tidak melibatkan peran pemeritah dalam sistem perekonomiannya. Tidak juga di negara yang menganut sistem kapitalis yang mengkehendaki peran swasta lebih dominan dalam mengelola perekonomiannya. Karena tidak ada satupun negara kapitalis di dunia ini yang menganut sistem kapitalis murni. Menurut Adam Smith, ahli ekonomi kapitalis, mengemukakan teorinya bahwa dalam perekonomian segala sesuatunya akan berjalan sendirisendiri menyesuaikan diri menuju kepada keseimbangan menurut mekanisme pasar. Tarik-menarik kekuatan dalam sistem perekonomian itu seperti dikendalikan oleh "the invisible hand", sehingga dengan demikian tidak memerlukan begitu banyak campur tangan pemerintah. Maka menurut Adam Smith peranan pemerintah hanya meliputi tiga fungsi saja, yaitu:

1. Memelihara keamanan dan pertahanan dalam negeri

2. Menyelenggarakan peradilan

3. Menyediakan barang-barang yang tidak bisa disediakan oleh swasta

Dlam masa sekarang ini, banyaknya perkembangan dan kemajuan akibat semakin majunya teknologi dan banyaknya penemupenemu baru serta semakin terbukanya perekonomian antar negara, menyebabkan begitu banyak kepentingan yang saling terkait dan berbenturan. Hal ini menyebabkan peran pemerintah semakin dibutuhkan dalam mengatur jalannya sistem perekonomian, karena tidak sepenuhnya semua bidang perekonomian itu dapat ditangani oleh swasta. Dengan 
demikian dalam sistem perekonomian modern, peranan pemerintah dapat dibagi dalam tiga bagian, yaitu:

1. Peranan alokasi

2. Peranan distribusi

3. Peranan stabilisasi

\section{Mengatur Distribusi Barang}

1. Peranan Alokasi

Peranan alokasi oleh pemerintah ini sangat dibutuhkan terutama dalam hal penyediaan barang-barang yang tidak dapat disediakan oleh swasta yaitu barang-barang umum atau disebut juga barang publik. Karena dalam sistem perekonomian suatu negara, tidak semua barang dapat disediakan oleh swasta dan dapat diperoleh melalui sistem pasar. Dalam hal seperti ini maka pemerintah harus bisa menyediakan apa yang di sebut barang publik tadi. Tidak dapat tersedianya barang-barang publik tersebut melalui sistem pasar disebut dengan kegagalan pasar. Hal ini dikarenakan manfaat dari barang tersebut tidak dapat dinikmati hanya oleh yang memiliki sendiri, tapi dapat dimiliki/dinikmati pula oleh yang lain, dengan kata lain, barang tersebut tidak mempunyai sifat pengecualian seperti halnya barang swasta. Contohnya seperti udara bersih, jalan umum, jembatan, dll.

Kegiatan dalam mengalokasikan faktor-faktor produksi maupun barang-barang dan atau jasa-jasa untuk memuaskan/memenuhi kebutuhan masyarakat. Jadi, kegiatan ini untuk memenuhi kebutuhankebutuhan individu maupun kebutuhan masyarakat yang secara efektif tidak dapat dipuaskan oleh mekanisme pasar. Contohnya dalam kegiatan pendidikan, pertahanan dan keamanan, serta keadilan.

Dalam sistem ekonomi islam menjamin tersedianya kebutuhan dasar bagi seluruh warga negara islam. Islam mewajibkan pihak yang kaya memenuhi kebutuhan kaum miskin dan melarat. Menurut AI-Qur'an, fakir dan miskin memiliki bagian di dalam harta orang kaya. Al-Qur'an menyatakan: "Dan orang-orang yang dalam hartanya tersedia bagian tertentu, bagi orang (miskin) yang meminta dan orang yang tidak mempunyai apa-apa (yang tidak mau meminta)." (QS. Al-Ma'arij [70]: 2425).

Menurut sebagian fukaha muslim, negara islam haruslah menyediakan jaminan soaial yang melindungi seluruh warga negaranya dan terutama sekali mencukupi kebutuhan dasar semua warga negaranya yang miskin, tertekan, cacat, dan menganggur yang tidak dapat mencari rezeki bagi diri mereka sendiri dan keluarganya. Jika negara islam tidak 
berhasil memenuhi kewajiban ini, maka negara tidak berhak untuk menuntut kesetiaan warga negaranya.

\section{Peranan Distribusi}

Peranan distribusi ini merupaka peranan pemerintah sebagai distribusi pendapatan dan kekayaan. Tidak mudah bagi pemerintah dalam menjalankan peranan ini, karena distribusi ini berkaitan erat dengan dengan masalah keadilan. Sedangkan masalah keadilan sudah ini sudah terlalu kompleks, sebab keadilan ini merupakan satu masalah yang bisa ditinjau dari berbagai presepsi, bahkan masalah keadilan ini juga tergantung dari pandangan masyarakat terhadap keadilan itu sendiri, karena keadilan itu merupakan masalah yang relatif dan dinamis. Kegiatan dalam mengadakan redistribusi pendapatan atau mentransfer penghasilan ini memberikan koreksi terhadap distribusi penghasilan yang ada dalam masyarakat.

Pemerintah dapat merubah distribusi pendapatn masyarakat baik secara langsung maupun tidak langsung. Secara langsung misalnya dengan pajak progresif, yaitu membebankan pajak yang relatif lebih besar bagi orang kaya dan rlatif lebih kecil bagi orang misin, disertai subsidi bagi golongan miskin. Secara tidak langsung, bisa melalui kebijaksanaan pengeluaran pemerintah, misalnya:pembangunan perumahan tipe sederhana (RS) dan tipe sangat sederhana (RSS) yang lebih banyak porsinya dibanding rumah mewah, untuk golongan pendapatn tertentu, subsidi untuk pupuk petani, dan lain sebagainya.

3. Peranan Stabilisasi

Kegiatan menstabilisasikan perekonomian yaitu dengan menggabungkan kebijakan-kebijakan moneter dan kebijakan-kebijakan lain seperti kebijakan fiskal dan perdagangan untuk meningkatkan atau mengurangi besarnya permintaan agregat sehingga dapat mempertahankan fullemployment dan menghindari inflasi maupun deflasi. Peranan tabilisasi pemerintah dibutuhkan jika terjadi gangguan dalm menstabilkan perekonomian, seperti: terjadi deflasi, inflasi, penurunan permintaan/penawaran suatu barang, yang nantinya masalah-masalah tersebut akan mengangkibatkan timbulnya masalah yang lain secara berturut-turut, seperti pengangguran, stagflasi, dll.

Permasalahannya sekarang ialah bagaimana menyelaraskan seluruh kebijaksanaan yang akan diterapkan jika terjadi suatu masalah, tanpa bertentangan dengan kebijaksanaan yang lain dan tanpa menimbulkan masalah baru. Baik itu kebijaksanaan dalam rangka peranan pemerintah sebagai alat untuk mengalokasikan sumber-sumber ekonomi agar efisien, distribusi pendapatan agar merata dan adil, serta 
stabilitas ekonomi. Demikian juga halnya kebijaksanaan dibidang-bidang lain. Oleh karenanya dituntut kebijaksanaan yang betul-betul seimbang dari pemerintah demi kesejahteraan masyarakat.

\section{Penetapan Harga}

\section{A. Pengertian Tas'ir}

Kata tas'ir berasal dari kata sa'ara-yas'aru-sa'ran, yang artinya menyalakan. Lalu dibentuk menjadi kata as-si'ru dan jamaknya as'ar yang artinya harga (sesuatu). Kata as-si'ru ini digunakan di pasar untuk menyebut harga (di pasar) sebagai penyerupaan terhadap aktivitas penyalaan api, seakan menyalakan nilai (harga) bagi sesuatu.

Dan para ulama merumuskan definisi tas'ir secara syar'i, yaitu: seorang imam (penguasa), wakilnya atau setiap orang yang mengurusi urusan kaum Muslim memerintahkan kepada para pelaku pasar agar tidak menjual komoditas kecuali dengan harga tertentu, mereka dilarang untuk menambah harganya hingga harga tidak membumbung atau mengurangi harganya hingga tidak memukul selain mereka. Jadi, mereka dilarang untuk menambah atau mengurangi dari harga yang dipatok demi kemaslahatan masyarakat. Artinya, negara melakukan intervensi (campur tangan) atas harga dengan menetapkan harga tertentu atas suatu komoditas dan setiap orang dilarang untuk menjual lebih atau kurang dari harga yang ditetapkan itu demi mempertimbangkan kemaslahatan masyarakat.

Fakta pematokan harga ini dapat kita saksikan dalam sistem ekonomi kapitalis pada saat ini. Pematokan harga itu dilakukan negara dengan alasan untuk melindungi kepentingan masyarakat atau kelompok masyarakat tertentu, misalnya kelompok produsen atau kelompok konsumen.

Pematokan harga terjadi dalam tiga bentuk: Pertama, pematokan harga secara fix. Kedua, pematokan harga tertinggi, yakni dengan menetapkan harga jual tertinggi. Contohnya adalah penetapan harga eceran tertinggi pupuk. Penjual dilarang menjual lebih dari harga tertinggi yang dipatok itu. Sebaliknya, mereka boleh menjual dengan harga yang lebih rendah. Ini ditetapkan demi melindungi konsumen. Ketiga, pematokan harga terendah seperti pematokan harga terendah gabah, dsb. Dalam hal ini pembeli dilarang membeli lebih rendah dari harga terendah itu. Sebaliknya, mereka boleh membeli dengan harga lebih tinggi dari harga itu. Ini dilakukan untuk melindungi produsen. Contohnya adalah penetapan harga terendah gabah untuk melindungi petani. Meski 
demikian, dalam praktiknya kebijakan ini terlihat tidak efektif. Pada saat panen raya, harga gabah tetap saja anjlok. Begitu juga harga pupuk; sering lebih tinggi dari pada harga eceran tertinggi yang ditetapkan Pemerintah.

\section{B. Pendapat Ulama Tentang Tas'ir}

\section{Pendapat Yang Tidak Setuju Dengan Tas'ir}

Menurut mereka Allah telah menetapkan seseorang untuk menjual komoditasnya dengan harga yang ia ridhai. dengan dalil yang mereka kemukakan bahwa Allah Swt. berfirman:

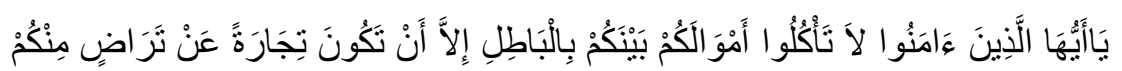

"Hai orang-orang yang beriman, janganlah kalian saling memakan harta sesama kalian dengan jalan yang batil, kecuali dengan jalan perniagaan yang berlaku dengan suka sama-suka di antara kalian." (QS an-Nisa [4]: 29).

Dan juga sabda Rasulullah saw yang berbunyi :

إِنََّّا الْبَيْعُ عَنْ تَرَاضِ

"Sesungguhnya jual-beli itu harus dengan saling ridha (antara penjual dan pembeli)." (HR Ibn Majah).

Tas'ir bertentangan dengan nash-nash tersebut. Sebab, tas'ir bermakna pemaksaan atas penjual dan atau pembeli untuk berjual-beli dengan harga tertentu. Ini melanggar kepemilikan seseorang karena kepemilikan itu bermakna seseorang memiliki kekuasaan atas harta miliknya. Karena itu, ia berhak menjual dengan harga yang ia sukai. Pematokan harga tentu akan menghalangi atau merampas sebagian kekuasaan seseorang atas hartanya. Sesuai keterangan nas syariah di atas, hal itu tidak boleh terjadi.

Dalam riwayat Abu Hurairah di atas, Rasulullah saw. pernah diminta untuk mematok harga, padahal harga sedang membubung tinggi. Seandainya tas'ir boleh, pastilah Rasulullah saw. memenuhi permintaan tersebut. Namun, Beliau ternyata tidak memenuhinya. Dalam riwayat Anas di atas, Beliau menjelaskan alasan mengapa Beliau tidak melakukannya. Beliau menjelaskan bahwa tas'ir merupakan kezaliman, sedangkan segala bentuk kezaliman adalah haram. Atas dasar itu, tas'ir hukumnya haram. Ini adalah pendapat jumhur ulama. 
Keharaman tas'ir ini berlaku secara umum untuk semua komoditi. Hal itu sesuai keumuman larangan tas'ir di atas. Rasulullah saw. menyatakan tas'ir sebagai kezaliman tanpa menyebutkan komoditinya. Ini artinya keharaman itu berlaku untuk semua jenis komoditi. Keharaman tas'ir juga berlaku dalam semua kondisi baik kondisi damai atau perang; baik harga anjlok, normal atau sedang membubung tinggi. Hal itu sesuai dengan kemutlakan nasnya.

Pada faktanya, pematokan harga merupakan dharar bagi umat. Pematokan harga itu akan mendorong terbentuknya pasar gelap yang jauh dari monitoring negara. Dengan begitu suplay barang ke pasar akan berkurang karena diperdagangkan di pasar gelap. Lalu harga di pasar normal akan mengalami kenaikan tanpa bisa dicegah oleh negara. Selain mendorong terbentuknya pasar gelap, pematokan harga juga bisa mempengaruhi tingkat produksi atau konsumsi. Pada tingkat tertentu mungkin bisa menyebabkan krisis ekonomi.

\section{Pendapat Setuju Dengan Tas'ir}

Pendapat yang membolehkan tas'ir bertentangan dengan mayoritas para ulama. Tetapi beberapa ahli, seperti Sa'id bin Musayyib, Rabiah bin Abdul Rahman dan Yahya bin Sa'id, menyetujuinya. Para pengikut Abu Hanifah berkata bahwa pemerintah harus menetapkan harga, hanya bila masyarakat menderita akibat peningkatan harga itu, di mana hak penduduk harus dilindungi dari kerugian yang diakibatkan oleh ketidak seimbangan harga.

Ibnu Taimiyah menafsirkan sabda Rasulullah SAW yang menolak penetapan harga, meskipun pengikutnya memintanya, itu adalah sebuah kasus khusus dan bukan aturan umum. Itu bukan merupakan merupakan laporan bahwa seseorang tidak boleh menjual atau melakukan sesuatu yang wajib dilakukan atau menetapkan harga melebihi nilai ganti yang sesuai. la membuktikan bahwa Rasulullah SAW sendiri menetapkan harga yang adil, jika terjadi perselisihan antara dua orang. Kondisi pertama, ketika dalam kasus pembebasan budaknya sendiri, la mendekritkan bahwa harga yang adil dari budak itu harus dipertimbangkan tanpa ada tambahan atau pengurangan (laa wakasa wa laa shatata) dan setiap orang harus diberi bagian dan budak itu harus dibebaskan. Kondisi kedua, dilaporkan ketika terjadi perselisihan antara dua orang, satu pihak memiliki pohon, yang sebagian tumbuh di tanah orang lain, pemilik tanah menemukan adanya bagian pohon yang tumbuh di atas tanahnya yang dirasa mengganggunya. la mengajukan masalah itu kepada Rasulullah SAW. Beliau memerintahkan pemilik pohon untuk menjual pohon itu kepada pemilik tanah dan menerima konpensasi atau 
ganti rugi yang adil kepadanya. Orang itu ternyata tak melakukan apaapa. Kemudian Rasulullah SAW membolehkan pemilik tanah untuk menebang pohon tersebut dan ia memberikan konpensasi harganya kepada pemilik pohon.

Ibnu Taimiyah menjelasklan bahwa "jika harga itu bisa ditetapkan untuk memenuhi kebutuhan satu orang saja, pastilah akan lebih logis kalau hal itu ditetapkan untuk memenuhi kebutuhan publik atas produk makanan, pakaian dan perumahan, karena kebutuhan umum itu jauh lebih penting dari pada kebutuhan seorang individu.

Itu sebabnya penetapan harga hanya mungkin dilakukan jika diketahui secara pasti ada kelompok yang melakukan perdagangan dan bisnis melakukan manipulasi sehingga berakibat menaikkan harga. Ketiadaan kondisi ini, tak ada alasan yang bisa digunakan untuk menetapkan harga. Sebab, itu tak bisa dikatakan pada seseorang yang tak berfungsi sebagai penyuplai barang dagangan, sebab tak akan berarti apa-apa atau tak akan adil. Argumentasi terakhir ini tampaknya lebih realistis untuk dipahami.

Menurut Ibnu Taimiyah, barang barang yang dijual di Madinah (pada zaman Nabi) sebagian besar berasal dari impor. Kondisi apapun yang dilakukan terhadap barang itu, akan bisa menyebabkan timbulnya kekurangan suplai dan memperburuk situasi. Jadi, Rasulullah SAW menghargai kegiatan impor tadi dengan mengatakan, "Seseorang yang mambawa barang yang dibutuhkan untuk kehidupan sehari-hari, siapapun yang menghalanginya sangat dilarang. Faktanya saat itu penduduk Madinah tidak memerlukan penetapan harga.

Ibnu Taimiyyah sebagaimana yang diutarakan Dr. Yusuf Qardhawi menggabungkan tentang dibolehkan atau tidaknya tas'ir diperbolehkan jika adil dan dilarang jika ada kedzaliman.

Dan Ibnu Khaldun pernah meneliti harga-harga di kota-kota. la membagi menjadi dua jenis, barang kebutuhan pokok dan barang mewah. Menurut dia bila suatu kota berkembang dan selanjutnya populasinya serta bertambah banyak maka harga-harga pokok akan mendapatkan penggandaannya. Akibat penawaran meningkat dan ini berarti penurunan harga. Adapun untuk barang-barang mewah, permintaannya akan meningkat sejalan dengan berkembangnya kota dan berubahnya gaya hidup. Akibatnya, harga barang mewah meningkat. Ibnu Khaldun juga menjelaskan mekanisme penawaran dan permintaan dalam menentukan harga keseimbangan. Secara lebih rinci ia menjabarkan tentang perkembangan pengaruh persaingan diantara konsumen untuk mendapatkan barang pada sisi pemintaan. Setelah itu ia menjelaskan pula 
pengaruh meningkatnya biaya poduksi karena pajak dan pungutanpungutan lain di kota tesebut pada sisi penawaran.

Dari keterangan di atas, tampak sekali bahwa penetapan harga hanya dianjurkan bila para pemegang stok barang atau para perantara di kawasan itu berusaha menaikkan harga. Karena itu jika tidak ada masalah dalam harga, lebih baik tidak menetapkan harga, tetapi membiarkan pasar yang akan berperan di dalamnya.

Berbeda dengan kondisi musim kekeringan dan perang, Ibnu Taimiyah merekomendasikan penetapan harga oleh pemerintah ketika terjadi ketidaksempurnaan memasuki pasar. Misalnya, jika para penjual menolak untuk menjual barang dagangan mereka kecuali jika harganya mahal dari pada harga normal (al-qimah al-ma'rifah) dan pada saat yang sama penduduk sangat membutuhkan barang-barang tersebut. Maka mereka diharuskan menjualnya pada tingkat harga yang setara, contoh sangat nyata dari ketidaksempurnaan pasar adalah adanya monopoli dalam perdagangan makanan dan barang-barang serupa. Dalam kasus seperti itu, pemerintah harus menetapkan harganya untuk penjualan dan pembelian mereka. Pemegang monopoli tak boleh dibiarkan bebas melaksanakan kekuasaannya, sebaliknya otoritas harus menetapkan harga yang disukainya, sehingga melawan ketidakadilan terhadap penduduk.

\section{Kesimpulan}

Dari beberapa uraian di atas, maka dapat di ambil kesimpulan sebagai berikut:

1. Peran negara dalam ekonomi ditentukan dari sistem perekonomian dan sistem pengelolaan ekonomi yang mereka gunakan.

2. Dalam sistem ekonomi sosialis negara ikut campur cukup dalam dengan perannya yang sangat dominan.

3. Dalam sistem ekonomi kapitalis negara tidak mempunyai peranan utama atau terbatas dalam perekonomian.

4. Dalam sistem ekonomi Islam, yang ditekankan adalah terciptanya pemerataan distribusi pendapatan. Selain itu negara berperan sebagai Pengawas (hisbah), yang mengawasi berjalannya sistem pasar sehingga terwujud mekanisme pasar bebas.

5. Fungsi negara sebagai "regulator" (pengatur) mencakup berbagai cara di mana negara melakukan intervensi melalui penggunaan hukum publik dengan langkah-langkah dan instrumentalitas dari suatu masyarakat yang tidak teratur. 
6. Peranan alokasi oleh pemerintah sangat dibuthkan terutama dalam hal penyediaan barang-barang yang tidak dapat disediakan oleh swasta yaitu barang-barang umum atau disebut jugabarang public.

7. Pematokan harga terjadi dalam tiga bentuk: Pertama, pematokan harga secara fix. Kedua, pematokan harga tertinggi, yakni dengan menetapkan harga jual tertinggi. Ketiga, pematokan harga terendah seperti pematokan harga terendah

8. Para ulama' ada yang setuju dengan tas'ir dan ada yang tidak setuju

\section{DAFTAR PUSTAKA}

P3El, Ekonomi Islam, Jakarta: Rajawali Pers, 2011.

Qardhawi, Yusuf, Norma dan Etika Ekonomi Islam, Gema Insani Press: Jakarta, 2000. yang diterjemahka oleh Zainal Arifin dan Dahlia Husin dari Daurul Qiyam wal Akhlam fil lqtishadil Islami.

Karim, Adiwarman, Ekonomi Islam Suatu Kajian Kontemporer, Gema Insani Press: Jakarta, 2003.

Asmuni, Drs., H., Penetapan Harga dalam Islam: Perpektif Fikih dan Ekonomi, http://pa-balikpapan.net/index.php (di akses tanggal 8 Desember 2012).

Utomo, Setiawan, Budi, Pematokan Harga oleh Pemerintah http://www.eramuslim.com/konsultasi/fikih-

kontemporer/pematokan-harga.htm (di akses tanggal 3 Desember 2012).

Mustika, Falery, At-Tas'ir (Pematokan Harga), http://www.mailarchive.com/aroen99society@yahoogroups.com/msg02707.html.

(di akses tanggal 5 Desember 2012). 